\title{
Technology of organization of network design in educational process
}

\author{
Galina Y. Semenova ${ }^{1, *}$ and Oksana A. Klimova ${ }^{2}$ \\ ${ }^{1}$ ISED RAE, Center for Supplementary Education and Carrier-Guiding of Learners, 105062, Moscow, Russia \\ ${ }^{2}$ FSBGEI Multiprofile School No. 1955, 129345, Moscow, Russia
}

\begin{abstract}
New forms, methods and facilities, allowing to useeffectively possibilities of information and communication technologies, are actively inculcated in a modern teaching and upbringing process. The organization of network design in education process supposes the use of the virtual education environment with application of services, allows to provide updating of content of education and to create conditions for satisfaction of various information and cognitive needs of pupils.
\end{abstract}

The structural upgrade of the education system in Russia has initiated the search of new approaches to education management. New forms, methods and facilities, allowing to use effectively possibilities of information and of communication technologies, to form an informative world outlook, to promote the adaptation of future graduates to the conditions of life and labour in the information society are actively inculcated in the modern teaching and upbringing process. The use of network projects in education is normally based on the activity and learner-centered approaches. The activity approach is implemented through learning new information via the activities of the learners. The learner-centered approach is implemented through each learner's subjective experience of gathering and using a new knowledge, planning activities, forecasting and evaluating results of such activities, and building cooperation with others.

The network project is normally any "joint education, research, creative or game activity of the partner learners based on computer telecommunication which has a common task, objective, coordinated methods and specific activities aimed at achieving the joint results thereof [1]."

Education network project management relies on the use of a virtual education environment with the use of services which provide for upgrading an education content and building the conditions to satisfy a variety of cognitive needs of learners.

The network projects help build education activities which allow learners to independently learn, set education goals, seek and deploy required means and methods to achieve these goals. The use of IT and communication technologies facilitates solution of the communicative and cognitive tasks, including the search, acquisition, processing, analysis, arrangement, transfer and interpretation of the information obtained.
The inclusion of networks projects in education process motivates the learners to act actively, uncover their creative potentials, to consider them from the different points of view, allows to achieve depth of reflections and the reasoned conclusions.Systematic practice of joint activity forms independence, responsibility for own activity and work of all group. Learners are taught to play various social roles, those of a leader, a doer, a joint activity manager, an idea generator, etc. Also, the involvement in network projects develops the skills of solving various issues which may help learners throughout their professional and social lives further on.

The development of a network project needs the definition of a common topic which a project will focus on; determination of the importance of a project, its target, fundamental tasks and trends which comprise a project, project stages ending with specific results, and participants.

Working on a network project requires the description of project's key elements, which basically are anticipated problems and possible solutions, a list of core education products expected at the end of a project, and assessment criteria and indices for results of a project.

An important segment of network projects is the skill of joint usage of Google social services: documents, maps, pictures, video clips, mail, web-sites, blogs, as well as the network communication skills and teamwork skills.

Network projects managed by the contemporary practical education provide new impulses and immense potential to learner's projects and research. A network project helps a learner step beyond a class, a classroom, or school; cooperate and perform the joint projects with fellow learners from various schools, places and

\footnotetext{
Corresponding author: gysemenova@mail.ru
} 
countries; exchange of information and obtain valuable communication experiences.

A network project has its particulars, and, if compared to learner's projects and research, a network project is wider and fuller than any regular project within the process of education due to its intrinsic specificities. Such particulars are primarily connected with remoteness of a network project, the variety of means of communication between participants, and diversity of possible representations of an end product and its translation.

The implementation of network projects in education process implies a distribution of roles amongst participants. They can be following: an author of the project, a network coordinator, a technical consultant, a scientific consultant, participants of the project, local coordinators.Not all network projects should include all these roles, of course. They may vary depending on targets of each specific network projects, possibilities of the teacher, and the particular arrangement of the network project. Also, fixed roles of participants and their specific functions will allow them to manage a full-fledged network project.

Equally important is the determination of stages of any network project. At the first stage, the problem which interests future participants of the network project is allocated. Then the subject of the network project, the purpose, tasks and estimated result is defined.

Another major part of a network project management technique is clear stage-by-stage tasksetting which helps learners to look at the right side of each project stage, and also acquaintance of participants of a network project with system of an assessment, criteria and indicators on which work on a project will be estimated.

The network project management is very timeconsuming; therefore the early definition of the deadlines is critical to focusing the learners on proper planning of their project performance. A large portion of the project is performed off class, but it is crucial for the teacher to use the information obtained by the learners independently from various sources in the classroom in order to deepen and broaden the education materials. As a result, the information gathered independently becomes more systematic and generalized.

A product of a network project may be publicized on a web-site as a post, a presentation, a video clip, etc. The representation form has to be defined before the implementation begins.

Functions of a network coordinator who drafts mailing lists, a project site and publicizes all projectcentered materials are also quite notable for a network project management.

A network project management involves some costs which are required to manage and publish a project on the Internet, thus, a small budget is vital, too.

Any good network cooperation also greatly depends on a prompt publication of a project information on the Internet. A publication may contain a name of a project, information about an author(s), a target, a deadline, participants' age, stages and anticipated results of a project. Any success of a network project is directly linked to how it was prepared.

The information about outcomes of a network project should be transparent and accessible to anyone who is willing to get to know about it. The discussion of results may be organized in a class where a content, management and technology of a network project could be discussed.

The organization of a network project pedagogically justified only in the case where a project concerns a collection of data in different countries, regions, and cities, as well as mapping observations of natural and social phenomena. Besides, a network project may include a comparative study of events, circumstances or facts for determining specific trends, hypotheses and decisions. A network project may become the basis for any joint cognitive, creative or gaming activities.

Another essential component of a network project is a preparedness of a teacher for a solution of various management, education and technology issues. The implementation of network projects greatly broadens functions of a teacher who acts as a project leader, as well as a manager, a technical advisor, etc. Therefore in the organization of network design in a teaching and upbringing process special training of a teacher of the organization and carrying out a network project is necessary.Teachers enthusiastically deploy network project techniques in their work. A good example is a teacher of geography at State-financed Education Institution School No. 1955 of Moscow, O.S. Chuikina.

Learners have successfully completed under the teacher's leadership such network projects as "I Get to Know Moscow", "The Holy Champion of Russian Lands", "Feed Well for Plants", etc.

A network project perfectly manages the remote cooperation of learners and a team leader. Since the completion of tasks and search for information are associated with the Internet, the realtime meetings of the group become unnecessary. Moreover, the participation in a network project allows each team member to fit work to their most convenient routines.

To be successful you need to assemble a team of students. At the same time we must remember that teamwork is possible not only for strong students, but also for those whose success in learning is not so good. Each student can have a role in the network project: some can gather the information, some can process it, and some can create the end-product using the right web-service.

No work is possible without the good management. For the network project, such management is based on the common progress table for all team members where each task is broken into a series of stand-alone issues. The table of this kind can trace activities of each participant and analyze their performance.

In addition to the progress table, opening of a topic in any social network also offers good results. The contemporary technologies allow a team leader to regularly contact team members, trace their activities 
and provide explanations as the work progresses. It is quite valuable for a team that their performance is followed. At the same time, any teamwork needs understanding of reasons for which a certain member may not work right away. This also wants a common contact place where the lack of necessary work can be discussed, as well as timelines for its completion.

Google Docs is a recommended tool to make the performance of each network project member available to an entire team. An obvious advantage of the cloud technology is that several members can edit and comment on a same document. Learners may add a required information whenever it is convenient for them, and a teacher may adjust a progress using notes. This makes teamwork more systematic and helps build the right direction of it. Also, cloud technologies make visible a name of a person who edits a document and any changes that they make.

A Google Docs group begins from an account file for project members. This is necessary to enable anyone who creates a new document make it accessible to an entire team or some of its members (as the case may be). A new document has to be created for each issue amongst project tasks. If the team members are new to the network project and Google Docs, this may be done by a leader. In future, members create new documents independently, after a team gets some experience and learn how to work together.

The characteristic trait of network projects is the presentation of results in various web-services. If learners acquire such skill during the implementation of a project, it is just perfect. However, it is recommendable to alternate a technical segment of a task amongst members on different stages of a project in order to achieve the above goal.

Another unambiguous advantage of a network project is peer assessment based on certain criteria and comparison of the results for different teams.

On the final stage and after general summing up of a project, each team member should be assessed.

The summingup stage has to include peer assessment of team members. Those who did not perform quite well should not be rejected, though. First of all, a learner may reconsider their work and do better later on. Secondly, if this is not the case, a future membership of such learner will be decided by a team instead of a leader. However, a teacher may not support any mistreatment of such students. The situation have to be quietly considered, and a reasons for which such a learner provides the inadequate feedback must be cleared out to explain that a team may not include a person whose work has to be done by others.
From practical experience, it is evident that the participation of school students in network projects is an effective way of shaping and development of the cognitive motivation, research, cooperation and communication skills. The possibility to pursue each one's convenient routine improves a learner's performance and makes it easier for a leader to trace the work done and adjust the progress yet to be achieved. Distance work with Google Docs manages general activities regardless of having free time by a learner and a teacher simultaneously and converts joint activities into fruitful co-creation [2].

As a result of network projects, school No. 1955 has a team of $9^{\text {th }}$ and $11^{\text {th }}$-grade students who intensely participate in network projects and get high expert marks at conferences and competitions. Due to the participation in the "I Get to Know Moscow" network project, the students performed indepth research of the history and development of Losinoostrovsky District in Moscow. Also, twelve papers by the learners have been published on the "Get to Know Moscow" portal, the "Territories" segment.

The participation of high school students in network projects helps them discover the undiscovered and find new solutions to the problems they face.

\section{References}

1. E.S. Polat, and M.Yu. Bukharkina, Sovremennyepedagogicheskie $i$ informatsionnye tekhnologii v sisteme obrazovaniya (Akademiya, Moscow, 2007) [In Rus)

2. O.S. Chuikina, and E.E. Sarycheva, Pedagogika I sovremennost', 6, 115 (2013) [In Rus] 